Article

\title{
Analysis of air quality by ventilation in house in the frame- work of the COVID-19 pandemic: the case of Spain
}

\author{
Patricia Aguilera-Benito ${ }^{1,}$ Carolina Piña-Ramirez ${ }^{2}$, Giacomo Viccione ${ }^{3}$ and Ester Lepore ${ }^{3}$ \\ 1 Departamento de Tecnología de la Edificación, Escuela Técnica Superior de Edificación, Universidad Poli- \\ técnica de Madrid, 28040 Madrid, Spain; patricia.aguilera@upm.es \\ 2 Departamento de Construcciones Arquitectónicas y su Control, Escuela Técnica Superior de Edificación, \\ Universidad Politécnica de Madrid, 28040 Madrid, Spain; carolina.pina@upm.es \\ 3 University of Salerno, via Giovanni Paolo II, 132, 84084 Fisciano, Italy; gviccion@unisa.it \\ * Correspondence: patricia.aguilera@upm.es
}

\begin{abstract}
After the arrival of a new airborne virus to the world, science is aiming to develop solutions to withstand the spread and contagion of the SARS-CoV-2 coronavirus. The most severe among the adopted measures is to remain in home isolation for a significant number of hours per day, in order to avoid the spreading of the infection in an uncontrolled way through public spaces. Recent literature showed that the major route of transmission is via aerosols produced especially in poorly ventilated inner spaces. With regard to contagion rates, accumulated incidence or number of hospitalizations due to COVID-19, Spain has reached very high levels, therefore this article develops a quantitative and qualitative analysis of the requirements established in Spain with respect to the European framework in reference to ventilation parameters indoors. For this, a case study has been analyzed, representing a common residence in current Spanish residential developments. Results show that the criteria established in the applicable regulations are not sufficient to ensure health as well as to avoid contagion by aerosols indoors.
\end{abstract}

Keywords: ventilation; indoor air quality; COVID-19; aerosols; Spain

\section{Nomenclature list}

\begin{tabular}{|l|l|}
\hline Abbreviation & \multicolumn{1}{|c|}{ Term } \\
\hline ACH & Air changes per hour \\
\hline CO & Carbon Monoxide \\
\hline $\mathrm{CO}_{2}$ & Carbon dioxide \\
\hline COVID-19 & Corona virus disease 2019 \\
\hline CTE & Technical code of the building \\
\hline EN & European Norm \\
\hline HS & Basic documenton salubrity \\
\hline IAQ & Indoor Air Quality \\
\hline IEQ & Indoor Environmental Quality \\
\hline IEQcat & Indoor Environmental Quality category for design \\
\hline NOX & Oxides of nitrogen \\
\hline ns & Crowding index per unit area \\
\hline O3 & Ozone \\
\hline OMS (WHO) & World Health Organization \\
\hline
\end{tabular}




\begin{tabular}{|l|l|}
\hline PM & Particulate Matter \\
\hline ppm & parts per million \\
\hline qB & ventilation rate for building materials \\
\hline Qop & specific external air flow per person \\
\hline qp & ventilation rate for people \\
\hline qv & minimum flow for housing \\
\hline R/h & Air renewal per hour \\
\hline SIMA & Italian Society of Environmental Medicine \\
\hline SO $_{2}$ & Sulfur dioxide \\
\hline UNE & A Spanish standard \\
\hline UNESCO & United Nations Educational, Scientific and Cultural Organization. \\
\hline UNI & Italian national unification body \\
\hline
\end{tabular}

\section{Introduction}

At the end of 2019 a new airborne virus "COVID-19" was first identified in Wuhan, China. The quick spreading soon turned into a worldwide pandemic, seeing that people does not have immunity against it, along with a high level of contagion and a significant mortality rate [1]. The first cases were registered in Europe at the end of January [2]. The first 100 infections are counted as day zero, which in Spain were reached on March 5, $2020[3,4]$. From that moment on, different governments have taken measures such as closure of airports [5], schools, commercial activities, restaurants, etc. [6-8].

With the arrival of the COVID-19 pandemic, people across the world have experienced remarkable changes to the way they live their lives at home. Suddenly, the society have had to face an involuntary confinement, from one day to the next, been obligated to stay indoors much longer than usual, sharing spaces no matter occupants are of the same nuclear family or not. Workers have had to start working remotely from buildings and both children and teenagers have had to follow and deal with online lessons [9-10].

Mankind is facing issues related to the ongoing pandemic that can definitely affect the quality of life, e.g. considering the importance of ventilation on the air distribution, determining comfort and health in indoor environments [11-12]. According to various studies, contagion is due to the exposure of aerosols that convey the virus through the environment, and this risk can be minimized with clean air derived from good indoor ventilation [13-18]. A well-ventilated home is beneficial to health. The air circulation allows it to be oxygenated, which facilitates the expulsion of dust particles and mites, regulates the humidity of the environment and eliminates bad odors. In addition, ultraviolet rays can act against some microorganisms, therefore, if possible, it is also beneficial for sunlight to flood the house. On the contrary, when the house is not well ventilated, in addition to favoring the spread of germs (especially in closed and humid environments), we can suffer energy dips, frequent headaches, sleep difficulties or respiratory symptoms may intensify, in addition to the increase in infections in times of pandemic like the one we are experiencing.

Therefore, it is evident the need to improve the indoor air quality, as it may contain atmospheric pollutants which can be divided, according to their physical nature, into gaseous and particulate matter, and according to their formation, into primary pollutants: sulfur dioxide (SO2), nitrogen oxides (NOx), carbon monoxide (CO) and 
secondary pollutants: ozone (O3) and particulate matter (PM) [19-23]. Electronic noses, shortly e-noses consisting of a sensor array and a pattern recognition algorithm, may be conveniently used as smart devices to monitor indoor air quality in living environment [24-26]. However, in order to avoid high concentrations of the above mentioned substances, it is necessary to have good indoor ventilation. Furthermore, the presence of people in confined spaces for a higher number of hours per day may imply an increase in the concentration of CO2 in our rooms [27, 28]. Obviously, with the increase of time spent indoors, increases the time of use of appliances, lighting, heating, etc., which can also increase the amount of $\mathrm{CO} 2$ released into the indoors $[29,30]$.

Indoor heating and cooling yield the primary source of energy consumption while the use of appliances is the most important factor in terms of $\mathrm{CO} 2$ emissions [31, 32]. Healthy environments may be, however, obtained through optimal systems that seek a balance between energy savings and optimal ventilation conditions [33-37]. According to the "Recommendations of the UNESCO Chair on Health Education and Sustainable Development \& the Italian Society of Environmental Medicine (SIMA)", a strong accumulation of $\mathrm{CO} 2$ can cause problems in people with lung conditions and can also decrease concentration and worker's and student's productivity [38-41].

An efficient living, work or study environment is therefore a fundamental requirement for building occupants to either live healthy or work productively. Thus, improving indoor air quality can be very important to increase productivity, and, moreover, to avoid the spread of the virus [42-45]. In order to reduce the likelihood of transmission via air, the WHO recommends a natural ventilation rate of at the least 60 liters per second and per person, and at least 6 air changes per hour [46-47]. In light of the carried literature review, some questions can be raised: what are the regulations in Spain and Europe in matter of ventilation parameters? Are indoor environments up to the task of adopting the imposed, yet hopefully transitory, "new way of life"? Can them be considered safe in terms of preventing contagion, safeguarding public health? And also, have them proper ventilation system, according new demands in times of pandemic? In the following we try to address the above posed questions.

\section{Materials and Methods}

The methodology used for the analysis of the air quality consists in the calculation of flow rates and $\mathrm{R} / \mathrm{h}$ of ventilation adopted indoors in Europe and Spain, considering the amount $\mathrm{CO}_{2}$ emitted per person in the framework of the new issued directives of COVID-19. To verify that the indoor ventilation is still adequate to the new requirements, the existing regulations at European level are analyzed in comparison to the Spanish regulations regarding the minimum measurements indoors, to finally choosing a standard home to make the comparison of both regulations.

\subsection{Regulations regarding ventilation}

The current legislation in Europe and Spain is analyzed to calculate the main parameters needed to maintain a healthy indoor air quality according to the applicable regulations. The factors that most influence the improvement of health are: air renewal per hour, the minimum ventilation flow, as well as the concentration of $\mathrm{CO} 2$ indoors. They will be studied according to the different legislation.

2.1.1. Minimum flow rates per house 
- For Europe:

For an additional comparison, we will also consider the European standard EN 16798: 2019 "Energy performance of buildings - Ventilation for buildings" will be considered, in which the quality of the indoor environment is taken into account by categories (Table 1), as well as the surface of the premises and the number of building residents who can be established.

Table 1. Description of the air quality categories in buildings. Source: EN 16798-2: 2019

\begin{tabular}{ccl}
\hline Category & Level of expectation & \multicolumn{1}{c}{ Explanation } \\
\hline IEQ I & High & $\begin{array}{l}\text { Should be selected for occupants with special needs } \\
\text { (children, elderly, and people with disabilities). }\end{array}$ \\
\hline IEQ II & Medium & The normal level used for design and operation. \\
\hline \multirow{2}{*}{ IEQ III } & \multirow{2}{*}{ Moderate } & $\begin{array}{l}\text { Will still provide an acceptable environment. Some risk of } \\
\text { reduced performance of the occupants. }\end{array}$ \\
\hline \multirow{2}{*}{ IEQ IV } & Low & $\begin{array}{l}\text { Should only be used for a short time of the year or in a space } \\
\text { with very short time of occupancy. }\end{array}$ \\
\hline
\end{tabular}

The ventilation flow through residential buildings is calculated based on the criteria established for predefined supplied ventilation air flow rates: Total ventilation for case 1 and supplied air for cases 2 and 3 in residential buildings (Table 2). Finally, the result with the highest value obtained is chosen, this being the most restrictive.

Table 2. Ventilation air flow rates. 3 different calculation methods (1), (2) and (3)

\begin{tabular}{|c|c|c|c|c|c|}
\hline \multirow[t]{2}{*}{ Category } & \multicolumn{2}{|c|}{$\begin{array}{l}\text { Total ventilation in } \\
\text { cluding infiltration } \\
\text { air (1) }\end{array}$} & \multirow{2}{*}{$\begin{array}{c}\text { Airflow } \\
\text { delivered per } \\
\text { person (2) } \\
1 \mathrm{~s}^{-1} \text { pax }^{-1}\end{array}$} & \multicolumn{2}{|c|}{$\begin{array}{c}\text { Supplied air flow based on } \\
\text { Indoor Air Quality (IAQ) } \\
\text { perceived by adapted people (3) }\end{array}$} \\
\hline & $1 / \mathrm{s} \mathrm{m}^{2}$ & Ach & & $q_{p}$ in $1 s^{-1} p a x^{-1}$ & $\mathrm{q}_{\mathrm{p}}$ in $1 \mathrm{~s}^{-1} \cdot \mathrm{m}^{-2}$ \\
\hline I & 0.49 & 0.7 & 10 & 3.5 & 0.25 \\
\hline II & 0.42 & 0.6 & 7 & 2.5 & 0.15 \\
\hline III & 0.35 & 0.5 & 4 & 1.5 & 0.1 \\
\hline IV & 0.23 & 0.4 & & & \\
\hline
\end{tabular}

- For Spain:

In Spain, according to CTE HS 3 "Quality of indoor air", the amount of minimum flow in $1 /$ s depending on the number of dry and humid areas present in the housing is taken into consideration (Table 3) [48]. 
Table 3. Minimum flow rate for constant flow ventilation in rooms. Source: CTE HS 3 [48].

\begin{tabular}{lccccc}
\hline & \multicolumn{5}{c}{ Minimum flow qvin 1 s } \\
\hline \multirow{2}{*}{ Housing type } & $\begin{array}{c}\text { Main } \\
\text { bedroom }\end{array}$ & $\begin{array}{c}\text { Rest of } \\
\text { bedrooms }\end{array}$ & $\begin{array}{c}\text { Living room and } \\
\text { dining rooms }\end{array}$ & $\begin{array}{c}\text { Minimu } \\
\text { m in total }\end{array}$ & $\begin{array}{c}\text { Minimum } \\
\text { per area }\end{array}$ \\
\hline & 8 & - & 6 & 12 & 6 \\
\hline 0 or 1 bedrooms & 8 & 4 & 8 & 24 & 7 \\
\hline 3 bedrooms & 8 & 4 & 10 & 33 & 8 \\
\hline
\end{tabular}

In order to calculate the value of the minimum flow qv in $1 \mathrm{~s}-1$, the number of bedrooms present in the housing (admission calculation) and the number of toilets, bathrooms or kitchens must be considered (extraction calculation). In this way, the final result of the flow of the house will be determined by the highest resulting value, whether of admission or extraction, being the same for both cases so that there are no pressure differences inside the property.

\subsection{2. $\mathrm{CO}_{2}$ concentration per housing}

- For Europe:

According to the EN-16798-2 standard, the maximum concentration of $\mathrm{CO}_{2}$ for each of the categories is shown in Table 4 [49] referring to premises in a housing.

Table 4. Design $\mathrm{CO}_{2}$ concentrations for living rooms and occupied rooms.

\begin{tabular}{ccc}
\hline Category & $\begin{array}{c}\text { Design } \Delta \mathrm{CO}_{2} \text { Concentrations } \\
\text { for Living Rooms (ppm) }\end{array}$ & $\begin{array}{c}\text { Design } \Delta \mathrm{CO}_{2} \text { concentrations } \\
\text { for rooms (ppm) }\end{array}$ \\
\hline I & 550 & 380 \\
\hline II & 800 & 550 \\
\hline III & 1350 & 950 \\
\hline IV & 1350 & 950 \\
\hline
\end{tabular}

- For Spain:

In Spain, as established by CTE HS 3 "Indoor air quality", it is considered that a sufficient flow of outdoor air must be provided in the living areas of the houses to achieve that in each area the average annual concentration of CO2 is less than $900 \mathrm{ppm}$ and that the annual accumulated CO2 that exceeds 1,600 ppm is less than 500,000 ppm . $h$, at the same time. [48].

\subsection{Minimal measurements of surfaces and heights in housings and premises according to Spanish regulations.}

For a comprehensive view of the calculation of renovations per hour, it has been necessary to verify the construction directives in Spain regarding the minimum surface area that makes up a home, also verifying the minimum net room height of housings in this country. In Spain, the dimensions of the houses are dictated by the Urban 
Regulations and the General Urban Planning of each city. In this case, a comparison has been made of the regulations currently used in some cities.

According to the Urban Regulations and General Urban Planning, in most of the cities in Spain the following parameters are expected: a minimum net room height of 2.5 $\mathrm{m}$ in dry areas, and at least $2.2 \mathrm{~m}$ height in wet areas. On the other hand, a double room has a minimum size of $10 \mathrm{~m}^{2}$ while the minimum for a single room is $6 \mathrm{~m}^{2}$. The minimum size for a living room is $10 \mathrm{~m}^{2}$, reaching $14 \mathrm{~m}^{2}$ if the kitchen is included. For a kitchen the minimum area is $5 \mathrm{~m}^{2}$, for a main bathroom $1.5 \mathrm{~m}^{2}$ and for a secondary bathroom of $1.1 \mathrm{~m}^{2}$. A studio for one person has a minimum floor area of $25 \mathrm{~m}^{2}$, whereas a house for two people should be at least of $37 \mathrm{~m}^{2}$.

The latest statistics data for the countries of the European Union shows that multifamily housing is the most common residence form in nine countries: Latvia $(66.2 \%)$, Spain (64.9\%), Estonia (61.5\%), Greece (60.6\%), Lithuania (59.5\%), Germany (56.3\%), Malta (53.8\%), Italy (52.6\%) and the Czech Republic (51.5\%), in the rest, single-family homes with larger surfaces prevail [50]. Spain is the second country in the European Union with the smallest housings, according to the latest registered data. In the last century, residential developments have been declining in size, with Spain being one of the countries with the smallest useful area per housing, and a large number of individual housing developments or studios have also been developed [51].

The overcrowding of cities, the increase of the land price in the larger ones, together with the economic crisis we are undergoing in recent years, has motivated urban developments to conceive a type of housing that is increasingly smaller and with a higher degree of overcrowding [52].

\subsection{Requirements recommended by governments due to the pandemic}

Due to the importance of reducing the concentration of different pathogens in the air to minimize the risk of COVID-19 infections, different governments have published implementation guides with restrictions regarding ventilation flow, air renewals per hour and the maximum concentration of $\mathrm{CO} 2$ [53-56].

In Spain, the government published different manuals on recommendations for ventilation systems based on the prevention of the spread of COVID-19. With regard to the minimum flow rate of ventilation it is recommended at least a value of $12.5 \mathrm{l} / \mathrm{s}$ per occupant [57]. Regarding the $\mathrm{CO} 2$ concentration, an optimum value of $500 \mathrm{ppm}$ is indicated [58]. It should also be considered that the WHO recommends 6 air changes per hour for a room [46-47].

\subsection{Analysis of the proposals applied to a case study}

To evaluate all the aforementioned aspects, a residential building is taken as case study, to carry out the analysis of the ventilation parameters. The chosen solution is sufficiently representative of most of the Spanish residential developments currently being carried out in urban development areas. The apartment (Figure 1) is conceived with the following formal and constructive characteristics: 


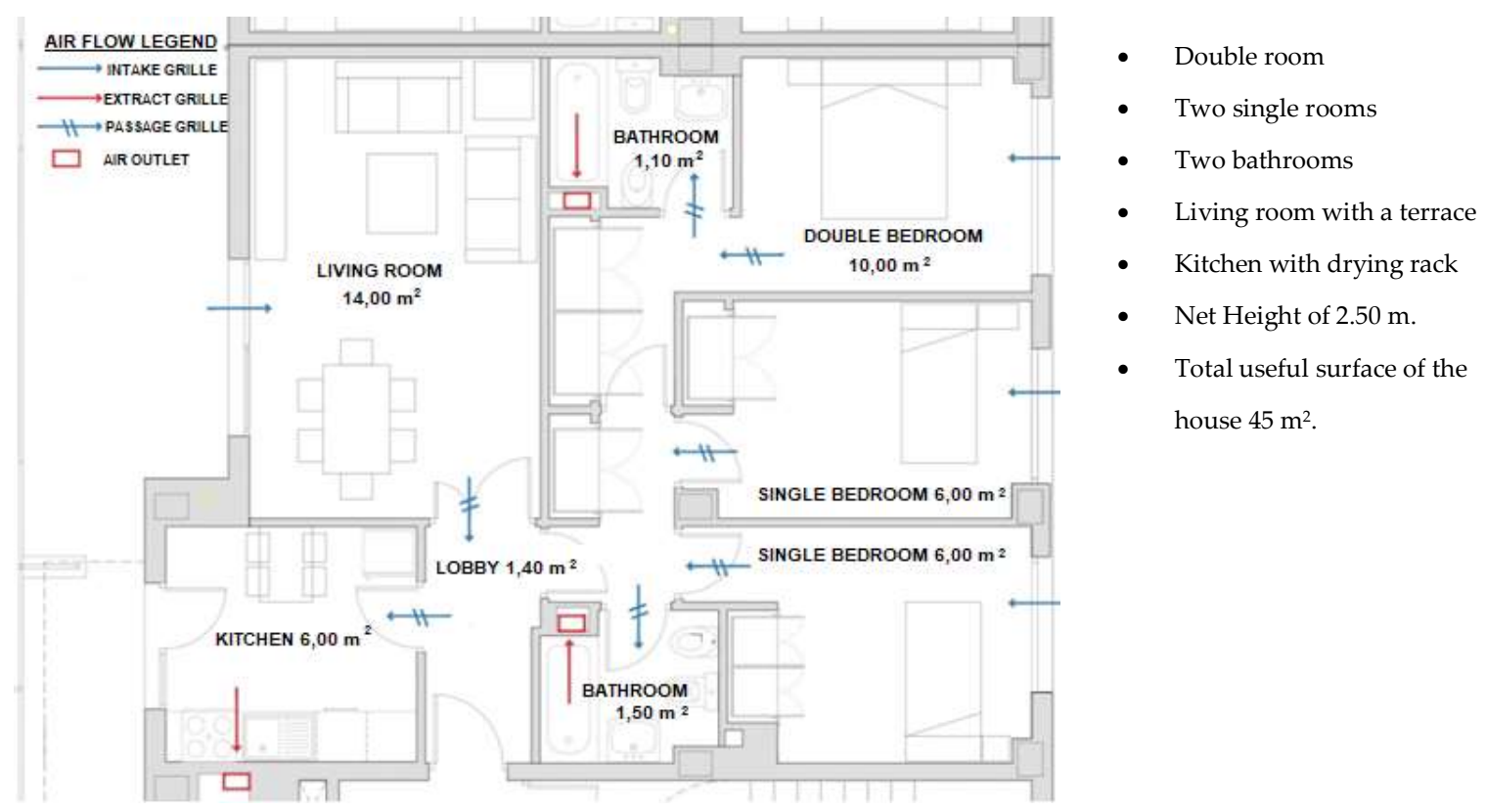

Figure 1. Apartment taken as case study

\section{Results}

The results, next discussed, indicate the influence of the chosen ventilation parameters on the apartment shown in Figure 1. In the following sections it is shown whether the current regulations meet the new criteria established during the COVID-19 pandemic.

\subsection{Comparative analysis of the regulations on the ventilation flow rate}

In order to make a comparison between the aforementioned regulations, a calculating procedure has been conceived for the apartment (Figure 1), subject to each of the considered legislations. The data related to category I (according to EN 16798-2) has been set as the optimal.

The ventilation flow rate according to CTE HS 3 standard has been calculated considering 3 bedrooms, a living room - dining, moreover it has been considered that the housing can be occupied by 4 people. As for Europe, the EN 16798-2 standard has been taken into account, where in its highest category we would have $10 \mathrm{l} / \mathrm{s}$ person.

The results of the total ventilation flow rate have been obtained from European regulations and have been compared to the recommendation provided today by the government of Spain due to the COVID- 19. As shown in Table 5, the higher flow rate is obtained according to the requirements set out in the directives of Spain. 
Table 5. Comparison of the Ventilation Flow results by regulations

\begin{tabular}{|c|c|c|c|}
\hline \multirow{2}{*}{$\begin{array}{c}\text { Surface } \\
\text { Total }\end{array}$} & \multicolumn{3}{|c|}{ Total ventilation flow } \\
\cline { 2 - 4 } & CTE HS 3 & Spanish recommendation for Covid-19 & EN 16798-2 \\
\cline { 2 - 4 } & Spain & Italy & Europe \\
\hline $\mathrm{m}^{2}$ & $1 / \mathrm{s}$ & $1 / \mathrm{s}$ & $4 / \mathrm{s}$ \\
\hline 45 & 33 & 50 & 40 \\
\hline
\end{tabular}

\subsection{Comparative analysis between the regulations on renewals per hour}

Table 6 resumes the results of calculations, made by considering the flow rates calculated above and the volume of the apartment under study.

Table 6. Comparison of the results of renovations per hour by regulations

\begin{tabular}{|c|c|c|c|}
\hline \multirow{2}{*}{$\begin{array}{c}\text { Volume } \\
\text { Total }\end{array}$} & CTE HS 3 & Spanish recommendation for Covid-19 & EN 16798-2 \\
\cline { 2 - 4 } & Spain & Italy & Europe \\
\hline $\mathrm{m}^{3}$ & $\mathrm{R} / \mathrm{h}$ & $\mathrm{R} / \mathrm{h}$ & $\mathrm{R} / \mathrm{h}$ \\
\hline 112.50 & 1.06 & 1.60 & 1.28 \\
\hline
\end{tabular}

As expected, the data that provides the greatest number of renovations per hour, for the same volume of housing, is the one with the highest flow rate. In this case, the recommendations of the Government of Spain with $1.60 \mathrm{R} / \mathrm{h}$ represents a higher value with respect to European regulations.

In addition, it must be taken into account that the WHO provides in its guide, to establish $6 \mathrm{R} / \mathrm{h}$ which imply for the case at hand a flow rate of $334 \mathrm{l} / \mathrm{s}$.

\subsection{Comparative analysis between the regulations on the concentration of $\mathrm{CO}_{2}$}

This analysis is carried out with the criteria established by the European and Spanish regulations and in the recommendation guides against COVID-19.

Table 7. Comparison of $\mathrm{CO}_{2}$ concentration results by the different regulations

\begin{tabular}{|c|c|c|c|}
\hline \multicolumn{4}{|c|}{$\mathrm{CO}_{2}$ concentration } \\
\hline CTE HS 3 & $\begin{array}{c}\text { Spanish recommendation for } \\
\text { Covid-19 }\end{array}$ & $\begin{array}{c}\text { EN 16798-2 } \\
\text { (Rooms) }\end{array}$ & $\begin{array}{c}\text { EN-16798-2 } \\
\text { (Living rooms) }\end{array}$ \\
\hline Spain & Spain & Europe & Europe \\
\hline ppm & Ppm & ppm & ppm \\
\hline 900 & 500 & 380 & 550 \\
\hline
\end{tabular}

The European standard EN-16798-2 is the one with the most restrictive values, reaching a maximum concentration of $380 \mathrm{ppm}$. As for living rooms, it establishes a maximum level of $\mathrm{CO}_{2}$ concentration of $550 \mathrm{ppm}$, very similar to the recommendations in times of COVID in Spain. 


\section{Conclusions}

From the results previously analyzed it can be concluded that the ventilation flow rates indicated by the considered regulations and guides of application in times of pandemic are insufficient to meet the renewal time advised by the $\mathrm{WHO}$, and consequently the decreasing of levels of $\mathrm{CO} 2$ levels indoors. However, in detail it is worth highlighting:

The ventilation flow established by the Spanish regulations presents better results than the European one, since it establishes a flow of $12.5 \mathrm{l} / \mathrm{s}$ per person due to ventilation requirements in the COVID-19 period. Therefore, it is verified that home confinement in this country has been able to work to mitigate the spread of the pandemic thanks to this reason [59-62].

As for the number of renewals per hour, the values are low for both Europe and Spain, in the case of a studio apartment lower than $2 \mathrm{R} / \mathrm{h}$ which means that it would be necessary to increase the criteria actually established by the various regulations to get closer to the $6 \mathrm{R} / \mathrm{h}$, recommended by the WHO.

Regarding the concentration of $\mathrm{CO} 2$, the values that are recommended not to exceed are set around $500 \mathrm{ppm}$. Spain may present a higher risk of pollutant concentration due to smaller volumes in the different areas of the houses compared to the minimum dimensions of houses established by other countries. Therefore, in Spain, an increase of the minimum measures of health concerning house ventilation is the preferred option, seen that it is a space where people spend more hours, in light of the fact there is no available legislation that establishes optimal measures that guarantee to avoid contagion through aerosols.

Acknowledgments: The authors gratefully acknowledge the support of the ERASMUS + Traineeship and Grupo de Investigación de Tecnología y Medio Ambiente (TEMA) at the School of Building Engineering at the Technical University of Madrid.

\section{References}

[1] Q. Li et al., «Early transmission dynamics in Wuhan, China, of novel coronavirus-infected pneumonia», New England Journal of Medicine, vol. 382(13), pp. 1199-1207, 2020. DOI: 10.1056/NEJMoa2001316

[2] G. Spiteri et al., «First cases of coronavirus disease 2019 (COVID-19) in the WHO European Region, 24 January to 21 February 2020», Euro Surveill. 2020; vol. 25(9). DOI: 10.2807/1560-7917.ES.2020.25.9.2000178.

[3] D. H. Glass, «European and US lockdowns and second waves during the COVID-19 pandemic», Mathematical Biosciences, vol. 330, p. 108472, 2020. DOI: 10.1016/j.mbs.2020.108472.

[4] I. Domínguez, P. Linde, A. Galocha, M. Zafra; D.Grasso; B. Andrino, «Spain: over one million official coronavirus cases», October 23, 2020. [Online]. Available at: https://english.elpais.com/society/2020-10-23/spain-over-one-million-official-coronaviruscases.html.

[5] S.S. Borrelli, «Politics goes viral as Italy struggles with outbreak. A cacophony of political reaction adds to confusion in European country hardest hit by coronavirus», February 25, 2020. [Online]. Available at: https://www.politico.eu/article/politicsgoes-viral-as-italy-struggles-with-outbreak/.

[6] Ordinanza del Ministro della salute 30 gennaio 2020, «Misure profilattiche contro il nuovo Coronavirus (2019 - nCoV)», Gazzetta Ufficiale Serie Generale n.26 del 01-02-2020. [Online]. Available at: http://www.governo.it/it/coronavirus-normativa. 
[7] Delibera del Consiglio dei Ministri 31 gennaio 2020, Dichiarazione dello stato di emergenza in conseguenza del rischio sanitario connesso all'insorgenza di patologie derivanti da agenti virali trasmissibili Gazzetta Ufficiale Serie Generale n.26 del 01-022020. [Online]. Available at: http://www.governo.it/it/coronavirus-normativa.

[8] Ley 33/2011 de 4 de octubre, General de Salud Pública. del. 6-12-2020. [Online]. Available at: https://www.boe.es/buscar/doc.php?id=BOE-A-2011-15623.

[9] Voss T., Wittwer J., «Teaching in times of corona: a look at the challenges from the perspective of research on learning and instruction 1 [Unterricht in Zeiten von Corona: Ein Blick auf die Herausforderungen aus der Sicht von Unterrichts- und Instruktionsforschung]», Unterrichtswissenschaft, vol. 48(4), pp. 601-627, 2020. DOI: 10.1007/s42010-020-00088-2

[10] Elnikova G.A., Nikulina N.N., Gordienko I.V., Davityan M.G., «Distance education in universities: Lessons from the pandemic» European Journal of Molecular and Clinical Medicine, vol. 7(1), pp. 3253-3529, 2020. ISSN: 25158260

[11] S. Gilani, H. Montazeri, B. Blocken, «CFD simulation of stratified indoor environment in displacement ventilation: Validation and sensitivity analysis», Building and Environment, vol. 95, pp. 299-313, 2015. DOI: 10.1016/j.buildenv.2015.09.010.

[12] Hamdy, M., \& Mauro, G. M, «Optimizing hybrid ventilation control strategies towards zero-cooling energy building», Frontiers in Built Environment, vol. 5, pp. 97, 2019. DOI: 10.3389/fbuil.2019.00097

[13] M. A. Zoran, R. S. Savastru, D. M. Savastru, M. N. Tautan, «Assessing the relationship between ground levels of ozone (O3) and nitrogen dioxide (NO2) with coronavirus (COVID-19) in Milan, Italy», Science of the Total Environment, vol. 740, p. 140005, 2020. DOI: 10.1016/j.scitotenv.2020.140005.

[14] Centro de Coordinación de Alertas y Emergencias Sanitarias - Análisis de Situación y evaluaciones del riesgo, Ministerio de Sanidad - Gobierno de España, del 1-2-2020. [Online]. Available at: https://www.mscbs.gob.es/profesionales/saludPublica/ccayes/analisisituacion/home.htm

[15] «Dati aggregati quotidiani Regioni / PPAA - Ministero della Salute - Istituto Superiore di Sanità», 2020. [Online]. Available at: https://github.com/pcm-dpc/COVID-19.

[16] M. Urrutia-Pereira, C. A. Mello-da-Silva, D. Solé, «COVID-19 and air pollution: A dangerous association?», Allergologia et Immunopathologia, vol. 48(5), pp. 496-499, 2020. DOI: 10.1016/j.aller.2020.05.004.

[17] T. Filippini, K. J. Rothman, A. Goffi, F. Ferrari, G. Maffeis, N. Orsini, M.Vinceti, «Satellite-detected tropospheric nitrogen dioxide and spread of SARS-CoV-2 infection in Northern Italy», Science of the Total Environment, vol. 739, p. 140278, 2020. DOI: 10.1016/j.scitotenv.2020.140278.

[18] J. M. Baldasano, «COVID-19 lockdown effects on air quality by NO2 in the cities of Barcelona and Madrid (Spain)», Science of the Total Environment, vol. 741, p. 140353, 2020. DOI: 10.1016/j.scitotenv.2020.140353.

[19] World Health Organization, «WHO Air quality guidelines for particulate matter, ozone, nitrogen dioxide and sulfur dioxide: Global update 2005», pp. 1-21, 2005. [Online]. Available at: https://apps.who.int/iris/handle/10665/69477.

[20] P. A. Garcia-Chevesich et al., «Respiratory disease and particulate air pollution in Santiago Chile: Contribution of erosion particles from fine sediments», Environmental Pollution, vol. 187, pp. 202-205, 2014. DOI: 10.1016/j.envpol.2013.12.028

[21] Y. Ogen, «Assessing nitrogen dioxide ( NO 2 ) levels as a contributing factor to coronavirus (COVID-19) fatality», Science of the Total Environment, vol. 726, p. 138605, 2020. DOI: 10.1016/j.scitotenv.2020.138605

[22] J. Madureira, I. Paciencia, J. Rufo, M. Severo, E. Ramos, H. Barros, E. de Oliveira Fernandes, «Source apportionment of CO2, PM10 and VOCs levels and health risk assessment in naturally ventilated primary schools in Porto, Portugal», Building and Environment, vol. 96, pp. 198-205, 2016. DOI: 10.1016/j.buildenv.2015.11.031.

[23] Coleman, J. R., \& Meggers, F., «Sensing of Indoor Air Quality-Characterization of Spatial and Temporal Pollutant Evolution Through Distributed Sensing», Frontiers in Built Environment, vol. 4, pp.28, 2018. DOI: 10.3389/fbuil.2018.00028

[24] S. Sironi, L. Eusebio, L. Capelli, M. Remondini, R.E. Del Rosso, «Use of an electronic nose for Indoor air quality monitoring», Chemical Engineering Transaction, vol. 40, pp. 73-78, 2014. DOI: 10.3303/CET1440013 
[25] G. Viccione, D. Spiniello, T. Zarra, V. Naddeo, «Fluid dynamic simulation of odour measurement chamber», Chemical Engineering Transaction, vol. 40, pp. 109-114, 2014. DOI: 10.3303/CET1440019

[26] G. Viccione, T. Zarra, S. Giuliani, V. Naddeo, V. Belgiorno «Performance Study of E-Nose Measurement Chamber for Environmental Odour Monitoring», Chemical Engineering Transaction, vol. 30, pp. 109-114, 2012. DOI: 10.3303/CET1230019

[27] B. Giechaskiel, «Gaseous and Particulate Emissions of a Euro 4 Motorcycle and E ff ect of Driving Style and Open or Closed Sampling Configuration», Sustainability (Switzerland), vol. 12(21), p. 9122, 2020. DOI: 10.3390/su12219122

[28] R. Rossi, R. Ceccato, M. Gastaldi, «Effect of road traffic on air pollution. Experimental evidence from COVID-19 lockdown», Sustainability (Switzerland), vol. 12(21), p. 8984, 2020. DOI: 10.3390/su12218984

[29] P. Aguilera, C. Viñas, A. Rodríguez, S. Varela, «Análisis de la influencia, en la demanda de climatización, de estrategias pasivas en viviendas con grandes superficies acristaladas, mediante un código de simulación. La casa Farnsworth = Analysis of the influence, in climate control demand, of passive st», Anales de Edificación, vol. 4(3), p. 34, 2018. DOI: 10.20868/ade.2018.3798

[30] J. Heinonen, A. Säynäjoki, J. Junnonen, A. Pöyry, S. Junnila, «Pre-use phase LCA of a multi-story residential building: Can greenhouse gas emissions be used as a more general environmental performance indicator», Building and Environment, vol. 95, p. 116-125, 2006. DOI: 10.1016/j.buildenv.2015.09.006.

[31] H. Jin, S. Lee, Y. Kim, S. Ha, S. Kim, S. Song, «Energy \& Buildings Estimation of energy use and CO2 emission intensities by end use in South Korean apartment units based on in situ measurements», Energy \& Buildings, vol. 207, p. 109603, 2020. DOI: 10.1016/j.enbuild.2019.109603.

[32] X. Yao, B. J. Dewancker, Y. Guo, S. Han, J. Xu, «Study on passive ventilation and cooling strategies for cold lanes and courtyard houses-a case study of rural traditional village in Shaanxi, China», Sustainability (Switzerland), vol. 12(20), p. 8687, 2020. DOI: $10.3390 /$ su12208687.

[33] C. Balocco, L. Leoncini, «Energy cost for effective ventilation and air quality for healthy buildings: Plant proposals for a historic building school reopening in the covid-19 era», Sustainability (Switzerland), vol. 12(20), p. 8737, 2020. DOI: 10.3390/su12208737.

[34] C. I. De Gaetani, A. Macchi, P. Perri, «Joint analysis of cost and energy savings for preliminary design alternative assessment», Sustainability (Switzerland), vol. 12(18), p. 7507, 2020. DOI: 10.3390/su12187507.

[35] M. Dudzik, «Towards characterization of indoor environment in smart buildings: Modelling PMV index using neural network with one hidden layer», Sustainability (Switzerland), vol. 12(17), 2020. DOI: 10.3390/su12176749.

[36] J. Lee, S. Park, T. Kim, «Development of a Ventilation System Using Window Cavity», Sustainability (Switzerland), vol. 12(20), p. 8391, 2020. DOI: 10.3390/su12208391.

[37] M. Darmanis, M. Çakan, K. P. Moustris, K. A. Kavadias, K. S. P. Nikas, «Utilisation of mass and night ventilation in decreasing cooling load demand», Sustainability (Switzerland), vol. 12(18), p. 7826, 2020. DOI: 10.3390/su12187826.

[38] M. Pulimeno, P. Piscitelli, S. Colazzo, A. Colao, A. Miani, «Indoor air quality at school and students' performance: Recommendations of the UNESCO Chair on Health Education and Sustainable Development \& the Italian Society of Environmental Medicine (SIMA)», Health Promotion Perspectives, vol. 10(3), pp. 169-174, 2020. DOI: 0.34172/hpp.2020.29.

[39] S. Gautam, «COVID-19: air pollution remains low as people stay at home», Air Quality, Atmosphere and Health, vol. 13(7), pp. 853-857, 2020. DOI: 10.1007/s11869-020-00842-6.

[40] B. Woodby, M. M. Arnold, G. Valacchi, «SARS-CoV-2 infection, COVID-19 pathogenesis, and exposure to air pollution: What is the connection?», Annals of the New York Academy of Sciences, pp. 1-24, 2020. DOI: 10.1111/nyas.14512.

[41] W. Espejo, J. E. Celis, G. Chiang, P. Bahamonde, «Environment and COVID-19: Pollutants, impacts, dissemination, management and recommendations for facing future epidemic threats», Science of the Total Environment, vol. 747, p. 141314, 2020. DOI: 10.1016/j.scitotenv.2020.141314.

[42] A. Kaushik, M. Arif, P. Tumula, O. J. Ebohon, «Effect of thermal comfort on occupant productivity in office buildings: Response surface analysis», Building and Environment, vol. 180, p. 107021. DOI: 10.1016/j.buildenv.2020.107021. 
[43] M. Abuhegazy, K. Talaat, O. Anderoglu, S. V. Poroseva, «Numerical investigation of aerosol transport in a classroom with relevance to COVID-19», Physics of Fluids, vol. 32(10), p. 103311, 2020. DOI: 10.1063/5.0029118.

[44] C. Sun, Z. Zhai, "The efficacy of social distance and ventilation effectiveness in preventing COVID-19 transmission», Sustainable Cities and Society, vol. 62, 2020. DOI: 10.1016/j.scs.2020.102390.

[45] Fürhapper, C., Habla, E., Stratev, D., Weigl, M., \& Dobianer, K., «Living Conditions in Timber Houses: Emission Trends and Indoor Air Quality», Frontiers in Built Environment , vol. 5, 2020. DOI: 10.3389/fbuil.2019.00151.

[46] World Health Organization «Gestión de la COVID-19 en hoteles y otras entidades del sector del alojamiento», [Online]. Available at: https://apps.who.int/iris/bitstream/handle/10665/334128/WHO-2019-nCoV-Hotels-2020.3-spa.pdf

[47] World Health Organization «Consideraciones para la cuarentena de los contactos de casos de COVID-19», [Online]. Available at: https://apps.who.int/iris/bitstream/handle/10665/333968/WHO-2019-nCoV-IHR_Quarantine-2020.3spa.pdf?sequence $=1 \&$ is Allowed $=\mathrm{y}$

[48] Gobierno de España, Ministerio de Fomento, «Documento Básico HS», pp. 1-184, 2019. [Online]. Available at: https://www.codigotecnico.org/pdf/Documentos/HS/DBHS.pdf.

[49] UNE-EN 15251:2008, «Parámetros del ambiente interior a considerar para el diseño y la evaluación de la eficiencia energética de edificios incluyendo la calidad del aire interior, condiciones térmicas, iluminación y ruido (Módulo 1-6). [Online]. Available at: https://www.une.org/encuentra-tu-norma/busca-tu-norma/norma?c=N0041732.

[50] Eurostat, «7 persons out of 10 in the EU live in a dwelling they own», November 2020, pp. 7-11, 2015. [Online]. Available at: https://ec.europa.eu/eurostat/web/products-press-releases/-/3-23112015-AP.

[51] C. Trilla Bellart, «La Política de vivienda en una perspectiva europea comparada», Revista de economía y finanzas de Castilla y León, ISSN 1139-6865, N. 6, 2003 (Mercado inmobiliario y política de vivienda), pp. 33-52.

[52] G. Manville, R. Greatbanks, «Performance management in hybrid organisations: A study in social housing», European Management Journal, vol. 38(3), pp. 533-545, 2020. DOI: 10.1016/j.emj.2020.04.006.

[53] ASHRAE Board of Directors, «ASHRAE Position Document on Infectious Aerosols», 2020. [Online]. Available at: https://www.ashrae.org/file\%20library/about/position\%20documents/pd_infectiousaerosols_2020.pdf

[54] Instituto para la diversificación y ahorro de energía «Sistema climatización de edificios y locales para la prevención de la propagación del SARS-CoV-2», [Online]. 2020.). Available at: https://www.mscbs.gob.es/profesionales/saludPublica/ccayes/alertasActual/nCov/documentos/Recomendaciones_de_operacion_y_ mantenimiento.pdf.

[55] Rapporto Istituto Superiore della Sanità (ISS) COVID-19 n. 20/2020 Rev. 2, «Indicazioni ad Interim per la sanificazione degli ambienti interni nel contesto sanitario e assistenziale per prevenire la trasmissione di SARS-CoV-2», pp. 1-20, 2020. [Online]. Available at: https://www.iss.it/rapporti-covid-19/-/asset_publisher/btw1J82wtYzH/content/id/5371609

[56] L. Bonadonna, G. La Rosa, G. Settimo, Eugenio Sorrentino, Enrico Veschetti, Luigi Bertinato, «Indicazioni sugli impianti di ventilazione/climatizzazione in strutture comunitarie non sanitarie e in ambienti domestici in relazione alla diffusione del virus SARS-CoV-2», pp. 1-30, 2020. [Online]. Available at: https://www.iss.it/documents/20126/0/Rapporto+ISS+COVID-19+33_2020.pdf.

[57] Govierno de España, Ministerio oara ka Transiciòn Ecològica y el Reto Demografico, IDAE, «Recomendaciones de operación y mantenimiento de los sistemas de climatización y ventilación de edificios y locales para la prevención de la propagación del SARS-
COV-2»,
pp.
$1-15$,
2020.
[Online].
Available
at:

https://www.mscbs.gob.es/profesionales/saludPublica/ccayes/alertasActual/nCov/documentos/Recomendaciones_de_operacion_y_ mantenimiento.pdf.

[58] J. Allen, J. Spengler, E. Jones, y J. Cedeno-Laurent, «Guía en 5 pasos para medir la tasa de renovación de aire en aulas», 2020. [Online]. Available at: https://andefil.com/wp-content/uploads/2020/09/guia_ventilacion.pdf 
[59] Gao, X., Chao, F., Yang, Y., Lee, S., Li, Q., Maron, M., \& Mostafavi, A., «Early Indicators of Human Activity during COVID-19 Period Using Digital Trace Data of Population Activities», Frontiers in Built Environment, vol. 6, pp. 223, 2020. DOI: 10.3389/fbuil.2020.607961

[60] L. Batlle-Bayer et al., «Environmental and nutritional impacts of dietary changes in Spain during the COVID-19 lockdown», Science of the Total Environment, vol. 748, p. 141410, 2020. DOI: 10.1016/j.scitotenv.2020.141410

[61] J. Heinonen, M. Jalas, J. K. Juntunen, S. Ala-Mantila, y S. Junnila, «Situated lifestyles: I. How lifestyles change along with the level of urbanization and what the greenhouse gas implications are - A study of Finland», Environmental Research Letters, vol. 8(2), p. 025003, 2013. DOI: 10.1088/1748-9326/8/2/025003.

[62] Á. Planchuelo-Gómez, P. Odriozola-González, M. J. Irurtia, y R. de Luis-García, «Longitudinal evaluation of the psychological impact of the COVID-19 crisis in Spain», Journal of Affective Disorders, vol. 277, pp. 842-849, 2020. DOI: 10.1016/j.jad.2020.09.018. 